\title{
PHYSIOTHERAPY STUDENTS AS A PARTNER FOR THE PREVENTION OF HEALTHCARE ASSOCIATED INFECTIONS
}

\author{
Karaali Kul Hayriye, ${ }^{1}$ Ilgin Duygu, ${ }^{1}$ Ozcan Ozlem, ${ }^{1}$ Arslan Tugba, \\ Arslan Serdar, ${ }^{3}$ Gunduz Turan, ${ }^{4}$ Limoncu E Mehmet ${ }^{4}$ \\ ${ }^{1}$ Department of Physiotherapy and Rehabilitation, Faculty of Health Sciences, \\ Manisa Celal Bayar University, Manisa, Turkey \\ ${ }^{2}$ Department of Ergotherapy, Faculty of Health Sciences, Cankırı Karatekin University, Cankır1, Turkey \\ ${ }^{3}$ Department of Physiotherapy and Rehabilitation, Faculty of Health Sciences, \\ Necmettin Erbakan University, Konya, Turkey \\ ${ }^{4}$ Manisa Health Services Vocational School, Manisa Celal Bayar University, Manisa, Turkey
}

Primljen/Received 10. 03. 2020. god.

Abstract: Background: Hand hygiene compliances of healthcare students have been examined extensively. However, there has been no study in this area for the students of the department of physiotherapy and rehabilitation. The aim was to evaluate hand hygiene compliance of the department of physiotherapy and rehabilitation students after a briefing on hand hygiene.

Methods: Before the summer practice, the students were briefed on hand hygiene. Then their hand hygiene compliance were assessed. Their sociodemographic characteristics, clinical summer practice data, and hand hygiene compliance based on the recommendations commented in the Centers for Disease Control and Prevention Guideline for Hand Hygiene in Health Care Settings were assessed with a questionnaire prepared by the researchers.

Results: Of 53 students, 52 met inclusion criteria. The average correct answer rate was $82.69 \%$. Students had inadequacies in selecting suitable hand hygiene techniques and in complying with hand hygiene indications in some situations related to their profession. Moreover, the students suggested that there was a great need for education $(n=24 ; 39.34 \%)$ and improvements in physical conditions $(\mathrm{n}=21 ; 34.43 \%)$.

Conclusions: As a conclusion, department of physiotherapy and rehabilitation students were aware of the importance of hand hygiene in terms of prevention of healthcare associated infections. However, for department of physiotherapy and rehabilitation students, educational programs about hand hygiene is needed in order to gain optimal competence and to be able to protect and improve health care workers and patients safety.
Prihvaćen/Accepted 28. 04. 2020. god.

Key words: hand hygiene, physiotherapy education, students.

\section{INTRODUCTION}

Many studies in the literature emphasize the necessity of examining the compliance of health students with hand hygiene $(\mathrm{HH})$ guidelines and the necessity to include occupation-specific programs to educational plans from the earliest period according to the needs assessed. These studies, which examine the compliance of health students with $\mathrm{HH}$ guidelines, frequently focus on students of medicine, nursing, and dentistry (1-16). In these studies, it is stated that the compliance rates with the $\mathrm{HH}$ guidelines are different according to the occupational category of the students $(2,10,14$, 15). Only in a limited number of studies, students of the department of physiotherapy and rehabilitation (DPR) have been shown to have moderate knowledge about $\mathrm{HH}$ and nosocomial infections $(17,18,19)$. Also in these studies, DPR students' number is fewer than the other healthcare students assessed in the same studies. When the situation is examined from the DPR students' point of view, it is clear that students often have to apply a variety of assessment and treatment methods, which require them to contact directly and indirectly with the patient and the inanimate environment using their hands and some devices. However, as a result of the literature research taking $\mathrm{HH}$ habits into consideration, there was not any research examining the DPR students' compliance with HH in the units where they carry out the clinical practice as a partner for the prevention of 
healthcare associated infections. For this reason, the aim of our study was to evaluate HH compliance of the DPR students after a briefing on $\mathrm{HH}$.

\section{MATERIAL AND METHODS Design and participants}

Our descriptive study was conducted with 52 students who had not received any education about $\mathrm{HH}$ and volunteered to participate in the survey. Study participants were chosen among 53 students in $2^{\text {nd }}$ year who were supposed to participate for the first time in a clinical summer practice which is included in the 4 year curriculum.

\section{Outcome measures}

The first part of evaluation form included open-ended questions about the age, height, body weight, body mass index, the status of having previously worked in a health institution and the presence of health workers among first degree relatives, gender and educational status of the students. The second and third sections consisted of open-ended questions that assessed the type of unit (inpatient and/or outpatient) where the summer practice was done. The final section included closed-ended questions composed of yes/no answers about having or not received any briefing on $\mathrm{HH}$, reports or warnings on complying with $\mathrm{HH}$ rules at the institution where the summer practice was conducted, and having or not being subjected to reports or warnings about complying with $\mathrm{HH}$ rules from patients. In that section, students were asked to rate the $\mathrm{HH}$ compliance of themselves as well as of the unit employees during the summer practice by visual analog scale (0-10; 0: poor / 10 excellent). The questions that assessed the HH compliance of the students were prepared by the researchers according to guideline (20). In this process, among the clinical activities performed by the students of the DPR during the summer practice, the most frequent ones were taken into consideration. These questions are closed-ended questions with the answers "yes, no, I do not remember" and "yes" is the correct answer for all. Finally, students were asked for their opinions about the factors that affected their compliance positively or negatively with the $\mathrm{HH}$ indications, and for their suggestions to improve compliance.

Firstly, having obtained approval from the local ethics committee of the Faculty of Medicine, students were informed about the research, and then the written consent of the volunteers was taken (Ethics Board Approval Number 24/06/2015/20478486-252). Secondly, the first part of the research questionnaire was applied using face-to-face interview technique. The informa- tion about the place, date and time of the briefing and evaluations to be carried out in the third and fourth steps were instructed. In the third step, two researchers briefed the students in the practice room according to guidelines $(20,21)$. Finally, after the students had completed their summer practice, the students were asked to complete sections 2.-4. of the questionnaire under the supervision of researchers in their own classroom environment.

\section{Data analysis}

For the analysis of the data was done using the SPSS 21.0 program. Data were presented by calculating mean and standard deviation, the number and percentage distributions. Chi-square analysis was performed to evaluate gender difference. $\mathrm{P}<0.05$ was accepted as significant difference.

\section{RESULTS}

Among a total of 53 students of the DPR that were apt to participate in second year summer practice. One student excluded, because previously she was a student of medical vocational highschool and participated in a course about $\mathrm{HH}$ practices and completed a summer practice in a clinical setting. Thirthy-eight $(73.08 \%)$ of the participants were females and $14(26.92 \%)$ were males. The mean age, body weight, height, and body mass index of the students were $20.52 \pm 0.70$ years, $62.54 \pm$ $11.59 \mathrm{~kg}, 1.67 \pm 0.09 \mathrm{~m}, 22.38 \pm 3.41 \mathrm{~kg} / \mathrm{m}^{2}$ respectively. None of the participants currently or previously worked in a healthcare facility and had received any formal $\mathrm{HH}$ education. Eight (15.39\%) of the students reported that they had a medical staff in first-degree relatives.

Within the scope of this research, $52(100 \%)$ of the students participated their clinical summer practices in the outpatient units and 31 (59.62\%) of them participated both in the outpatient and inpatient units where the physiotherapy and rehabilitation program was implemented. Thirteen (25\%) stated that they got education about HH where they completed their summer practice. Thirthy-five $(67.31 \%)$ of the students stated that they were informed about paying attention to $\mathrm{HH}$ indications, and $4(7.69 \%)$ of the students stated that they were asked by the patients to comply with these rules.

The self-rated HH compliance scores given by the students over 10 points to themselves and to the employees of the unit they worked together were $7.98 \pm$ 1.62 (min-max; 4-10) and $6.83 \pm 2.15$ (min-max; $1-10)$, respectively.

The correct answer rates about $\mathrm{HH}$ compliance of the students was $82.69 \%$ on average (Table $1 \mathrm{~A}$ and 1B). When the gender difference was considered, only 
Table 1A. Distribution of students' compliance with hand hygiene indications

\begin{tabular}{|c|c|c|c|}
\hline & Questions & Answers & n (\%) \\
\hline 1 & $\begin{array}{l}\text { Have you performed HH when your hands were visibly dirty or conta- } \\
\text { minated with proteinaceous material or were visibly soiled with blood } \\
\text { or other body fluids? And have you washed your hands with either a } \\
\text { non-antimicrobial soap and water or an antimicrobial soap and water? }\end{array}$ & $\begin{array}{l}\text { No } \\
\text { I don't remember } \\
\text { Yes }\end{array}$ & $\begin{array}{l}15(28.85) \\
4(7.69) \\
33(63.46)\end{array}$ \\
\hline 2 & $\begin{array}{l}\text { When your hands were not visibly soiled, have you used an alcohol-ba- } \\
\text { sed hand rub for routinely decontaminating hands in all other clinical } \\
\text { situations described in items 3-8? Alternatively, have you washed your } \\
\text { hands with an antimicrobial soap and water in all clinical situations de- } \\
\text { scribed in items 3-8? }\end{array}$ & $\begin{array}{l}\text { No } \\
\text { I don’t remember } \\
\text { Yes }\end{array}$ & $\begin{array}{l}23(44.23) \\
2(3.85) \\
27(51.92)\end{array}$ \\
\hline 3 & $\begin{array}{l}\text { Have you decontaminated your hands before having direct contact with } \\
\text { patients? }\end{array}$ & $\begin{array}{l}\text { No } \\
\text { I don't remember } \\
\text { Yes }\end{array}$ & $\begin{array}{c}13(25.0) \\
2(3.85) \\
37(71.15)\end{array}$ \\
\hline 4 & $\begin{array}{l}\text { Have you decontaminated your hands after contact with a patient's in- } \\
\text { tact skin (e.g., when taking a pulse or blood pressure, mobilizing and } \\
\text { exercising the patient, etc.)? }\end{array}$ & $\begin{array}{l}\text { No } \\
\text { I don't remember } \\
\text { Yes }\end{array}$ & $\begin{array}{c}2(3.85) \\
1(1.92) \\
49(94.23)\end{array}$ \\
\hline 5 & $\begin{array}{l}\text { Have you decontaminated your hands after contact with body fluids or } \\
\text { excretions, mucous membranes, nonintact skin, and wound dressings } \\
\text { when your hands were not visibly soiled? }\end{array}$ & $\begin{array}{l}\text { No } \\
\text { I don't remember } \\
\text { Yes }\end{array}$ & $\begin{array}{c}1(1.92) \\
- \\
51(98.08)\end{array}$ \\
\hline
\end{tabular}

Table 1B. Distribution of students 'compliance with hand hygiene indications

\begin{tabular}{|c|c|c|c|}
\hline & Questions & Answers & n (\%) \\
\hline 6 & $\begin{array}{l}\text { Have you decontaminated your hands when moving from a contamina- } \\
\text { ted-body site to a clean-body site during patient care? }\end{array}$ & $\begin{array}{l}\text { No } \\
\text { I don't remember } \\
\text { Yes }\end{array}$ & $\begin{array}{c}- \\
2(3.85) \\
50(96.15)\end{array}$ \\
\hline 7 & $\begin{array}{l}\text { Have you decontaminated your hands after contact with inanimate ob- } \\
\text { jects (including medical equipment, electrotherapy and exercise equip- } \\
\text { ment etc.) in the immediate vicinity of the patient? }\end{array}$ & $\begin{array}{l}\text { No } \\
\text { I don'tremember } \\
\text { Yes }\end{array}$ & $\begin{aligned} & 15(28.85) \\
& 3(5.77) \\
& 34\end{aligned}$ \\
\hline 8 & Have you decontaminated your hands after removing gloves? & $\begin{array}{l}\text { No } \\
\text { I don't remember } \\
\text { Yes }\end{array}$ & $\begin{aligned} 6(11.54) \\
1(1.92) \\
45(86.54)\end{aligned}$ \\
\hline 9 & $\begin{array}{l}\text { Before eating something, have you washed your hands with a non-anti- } \\
\text { microbial soap and water or with an antimicrobial soap and water? }\end{array}$ & $\begin{array}{l}\text { No } \\
\text { I don’t remember } \\
\text { Yes }\end{array}$ & $\begin{array}{c}- \\
- \\
52(100)\end{array}$ \\
\hline 10 & $\begin{array}{l}\text { After using a restroom, have you washed your hands with a non-anti- } \\
\text { microbial soap and water or with an antimicrobial soap and water? }\end{array}$ & $\begin{array}{l}\text { No } \\
\text { I don't remember } \\
\text { Yes }\end{array}$ & $\begin{array}{c}- \\
- \\
52(100)\end{array}$ \\
\hline
\end{tabular}

after contact within animate objects (including medical equipment, electrotherapy and exercise devices etc.) in the immediate vicinity of the patient, women $(85.29 \%$, $\mathrm{n}=29)$ were found to have more correct answer rate than men $\left(\mathrm{n}=5,14.71 \% ; \mathrm{X}^{2}=7.452, \mathrm{p}=0.010\right)$.
The distribution of the factors that affected the students positively ( 80 factors in total) and negatively (75 in total) on their $\mathrm{HH}$ practices were presented in Table 2. The suggestions (61 in total) of the students to improve HH compliance were shown in Table 3. 
Table 2. Positive and negative factors affecting HH compliance of DPR students

\begin{tabular}{|l|c|}
\hline Positive Factors & n (\%) \\
\hline Self-protection & $35(43.75)$ \\
\hline Protecting patients from diseases & $22(27.50)$ \\
\hline Having education and information about HH & $6(7.5)$ \\
\hline Easy access to the products needed to practice hygiene, taps, sinks, soap, water, etc. & $5(6.25)$ \\
\hline $\begin{array}{l}\text { Positive attitudes of other students and their working environment and of other employees } \\
\text { towards hygienic habits }\end{array}$ & $5(6.25)$ \\
\hline Individual attitudes of patients towards HH & $4(5)$ \\
\hline Presence of personal safety \& hygiene signs in the working environment & $3(3.75)$ \\
\hline Negative Factors & \\
\hline The use of gloves & $20(26.67)$ \\
\hline Not enough time & $16(21.33)$ \\
\hline Forget fulness & $15(20.00)$ \\
\hline Not feeling the necessity & $5(6.67)$ \\
\hline Lack of tap or handwashing facilities & $5(6.67)$ \\
\hline Sinks that are not easily accessible & $5(6.67)$ \\
\hline Lack of soap or other hand washing agents and hygienic materials & $4(5.33)$ \\
\hline Not having enough number of sinks & $3(4.00)$ \\
\hline Irritation and dryness of hand-skin due to hand washing agents & $2(2.67)$ \\
\hline
\end{tabular}

Table 3. Suggestions to improve HH compliance of DPR students

\begin{tabular}{|l|c|}
\hline Suggestions & n (\%) \\
\hline Briefing/education & $24(39.34)$ \\
\hline Improving water, sanitation and hygienic conditions & $15(24.59)$ \\
\hline Usage of health\&safety signs and posters for HH & $12(19.67)$ \\
\hline Facilitating access to disinfectants for HH & $6(9.84)$ \\
\hline Maintaining adequate nurse-to-patient ratio for the delivery of quality patient care & $3(4.92)$ \\
\hline Conducting hygienic inspections & $1(1.64)$ \\
\hline
\end{tabular}

\section{DISCUSSION}

With this study, DPR students have been shown to be aware of the importance of $\mathrm{HH}$ in terms of the prevention of HCAIs, and it has been revealed that in addition to the need for improvements in the physical conditions, there was a great need and demand for education.

In our study, the rate of compliance assessed by the questionnaire following DPR students' clinical practice was $82.69 \%$. However, the correct response rates were under average for the questions of performing $\mathrm{HH}$ after contact with "inanimate surfaces" and "after contact with each patient" and for the questions related to the method that should be used for HH when the hand is "visibly dirty/soiled" and "not visibly soiled". These results were higher than previous studies'. In the studies where $\mathrm{HH}$ compliances of students were evaluated by questionnaire, Mahmood et al. emphasized that $52 \%$ of the nursing students used alcohol-based hand rubbing technique (9). Similarly, in medical students, Graf et al. determined the compliance rate to be $52.5 \%$ (5). Ibrahim et al. stated that only $75 \%$ of the medical students had washed their hands with each patient before and after contact (7). On the otherhand, in two different studies realized by direct observation method, the average $\mathrm{HH}$ compliance rates in medical students were found to be $17 \%$ and $9.5 \%(1,8)$. In addition, Herbert et al. showed that medical students' self-reported compliance of $49 \%$ was higher than the disinfection rates according to $\mathrm{HH}$ guidelines of $43 \%$ (6). Those results suggest that the evaluation method is a factor affecting the compliance rate and should be taken into consideration during the interpretation of the results. Another reason why the overall averages were higher than the ones figured in the 
studies obtained from a literature research might be associated with the fact that, students were assessed after one month of summer practice following the HH briefing which is an important predictor of $\mathrm{HH}$, and that they were in their early years of studying introductory classes in terms of physiotherapy and rehabilitation education, which is in accord with the study results of Cruz et al. They have also been emphasizing that having positive attitudes about $\mathrm{HH}$ practices is one of the most important predictors of compliance with $\mathrm{HH}$ (4). To the question "I adhere to correct $\mathrm{HH}$ practices at all times" which was asked to determine the students' attitudes towards $\mathrm{HH}$, the nursing students' answer was $61.8 \%$ (10), $61 \%$ (12), 62.4\% (2) and medical students' answer was $21.4 \%$ (10), $20.9 \%$ (2). Cruz et al. found that $59.49 \%$ of the women and $(58.25 \%)$ of the men answered "I absolutely agree", and $29.11 \%$ of the women and $22.33 \%$ of the men answered "I agree" (3). In our study, the mean self-rated compliance score was $7.98 \pm 1.62$ (min-max; 4-10). This suggested that the DPR students' higher compliance rates should be related to the positive attitudes about HH. Furthermore, in our study, 21\% of the DPR students responded correctly to all questions. While the rates of nursing students having "good" practice scores were $14 \%$ (2), $29.8 \%$ (4) and $25.24 \%$ (3) in males, $30.19 \%$ (3) in females, for medical students it was $2 \%$ (2). Our "good" practice score was close to the nursing students', but higher than the medical students' score. It is reasonable to assume that there may be professional differences at this point. In the light of these results obtained we concluded that DPR students were aware of $\mathrm{HH}$, but they had inadequacies in selecting the $\mathrm{HH}$ technique for some situations and in complying with some of the $\mathrm{HH}$ indications.

Accessibility to wash basins, water, and disinfectants are among the most important factors that increase HH compliance $(22,23)$. In many studies it is found that students enumerated not having water and soap (2, $8,11,24)$, inadequate sinklayout $(8,11,24)$, laziness $(5,16,24)$, not having time $(5,8,11,16,25)$, and forgetting $(3,5,8,10,16,24)$ as negative reasons. Not having time and lack of personnel are also important resource shortage $(8,22)$. In addition, the use of reminder tips is an other factor that increases the compliance of health care workers with guidelines $(2,22)$. In the context of these studies and our data, it was thought that HH compatibility could be improved positively by determining the needs proper to the type of hospital/clinic, by planning special arrangements according to the needs, by using warning signs/posters, etc., by developing physical conditions and facilitating access to products, and by planning the workflow.

"To prevent and to protect from diseases" stand among the most important factors why students and he- althcare workers perform $\mathrm{HH}(8,11,22)$. In our study too, since the students singled out those two as the most important factors in complying with $\mathrm{HH}$, so this was thought to be a sign of our students' awareness of performing $\mathrm{HH}$ to protect the health of both the patient and the healthcare worker. Also, it has been found that among the students of medicine, nursing and dentistry there was a belief in the form of "I do not have to do HH because I use gloves" (1, 10, 16, 18, 25). However, Snow et al., on the contrary, determined that students who used gloves were more likely to perform $\mathrm{HH}$ (13). They reported that this might have been related to the type of patient being taken. Al-Naggar et al. pointed out that among the most important barriers for medical students, the feeling that their hands are not so dirty as to cause infections was the most basic barrier (24). Martinez et al. found that some physiotherapy students had beliefs about $\mathrm{HH}$ recommendations such that $\mathrm{HH}$ should only be performed if there is a risk of infection (18). In our study, the most important negatively affecting reason was "no $\mathrm{HH}$ is needed if gloves are available". In addition to this, other reasons were "not enough time, forgetfulness and not feeling the necessity". All of these results have shown that the students of the DPR realized the importance of $\mathrm{HH}$, and the most important need of DPR students is to get an education.

During the professional socialization process, students view other team members they work with as role models in terms of performing $\mathrm{HH}(2,5,7,10,13,16$, $19,22,25,26)$. Moreover, the patient's individual attitudes towards $\mathrm{HH}$ is also important factor in terms of $\mathrm{HH}$ practices $(8,20,22,27-29)$. It is also an important requirement to create and maintain an organizational culture as much as the efforts of individual team members to comply with $\mathrm{HH}$ guidelines (22). In the light of these data and our results, it should not be forgotten that while training programs and campaigns are planned to improve the HH compliance of the students, clinical and academic supervisors as well as the patient are also part of the team. At the same time, it is necessary to give importance to organizational culture.

There are studies showing that gender has no effect on parameters such as hand washing frequency $(11,30)$, knowledge level $(3,19,31)$, attitudes (31), awareness of theWHO's five-indications for $\mathrm{HH}$ (1), and compliance (1). On the other hand, there are also studies showing that women perform better self-assessment of their level of knowledge and compliance in terms of hygiene guidelines (6), had more positive attitudes and self-reported performance than men, and men had better $\mathrm{HH}$ practice scores than women (3). Cruz et al. pointed out male gender as the most important predictor for $\mathrm{HH}$ practice, too (4). In our study, it was seen that only in the case of "after contact with ina- 
nimate objects in the immediate vicinity of the patient", women had a more correct response rates than men. It was thought that future studies could help in the development of educational materials that will take into account the occupational effect of gender.

One of the most important limitations of our research is that firstly, it is a cross-sectional study which examines 52 students of the DPR of one university only. This may limit the generalizability of the results. Secondly, in our study, students' compliance with HH practices has been assessed by self-report questionnaires and face-to-face interview method. This method might have caused students to have higher HH compliance rates than observed. Besides this, the Hawthorne effect which might be generated by this kind of observation method might also have been eliminated again by itself as well. Lastly, the class and experience may be a factor that may affect $\mathrm{HH}$ compliance was also included in the literature as an information $(4,5,7$, 13-16, 32). This point should be taken into account in future studies.

\section{CONCLUSION}

As a result, DPR students were found to be aware of the importance of practicing $\mathrm{HH}$ in order to prevent
HCAIs. However, they had inadequacies in selecting suitable $\mathrm{HH}$ techniques and in complying with $\mathrm{HH}$ indications in some situations related to their profession. Moreover, the students suggested that there was a great need for education and improvements in physical conditions. In view of these results, it was thought that $\mathrm{HH}$ education which would start from the early period and would continue through out their education and that their effects on the students' HH compliances should be evaluated at frequent intervals.

\section{Abbreviations}

HH - Hand Hygiene

DPR - Department of Physiotherapy and Rehabilitation

\section{Acknowledgement: None.}

Conflict of Interests: The authors declare that there are no conflicts of interest related to this article.

\section{Funding: None}

\section{Licensing}

This work is licensed under a Creative Commons Attribution 4.0 International (CC BY 4.0) License.

\title{
Sažetak
}

\section{STUDENTI FIZIOTERAPIJE KAO PARTNERI U PREVENCIJI INFEKCIJA POVEZANIH SA ZDRAVSTVENOM NEGOM}

\author{
Karaali Kul Hayriye, ${ }^{1}$ Ilgin Duygu, ${ }^{1}$ Ozcan Ozlem, ${ }^{1}$ Arslan Tugba, ${ }^{2}$ \\ Arslan Serdar, ${ }^{3}$ Gunduz Turan, Limoncu E Mehmet ${ }^{4}$ \\ ${ }^{1}$ Department of Physiotherapy and Rehabilitation, Faculty of Health Sciences, \\ Manisa Celal Bayar University, Manisa, Turkey \\ ${ }^{2}$ Department of Ergotherapy, Faculty of Health Sciences, Cankır1 Karatekin University, Cankır1, Turkey \\ ${ }^{3}$ Department of Physiotherapy and Rehabilitation, Faculty of Health Sciences, \\ Necmettin Erbakan University, Konya, Turkey \\ ${ }^{4}$ Manisa Health Services Vocational School, Manisa Celal Bayar University, Manisa, Turkey
}

Uvod: Higijena ruku, koja je značajan faktor za prevenciju infekcija, koje se javljaju u zdravstvenom sistemu je opsežno ispitivana. Međutim, ne postoje studije u ovoj oblasti kod studenata iz odseka za fizioterapiju i rehabilitaciju. Cilj ove studije bio je da se proceni komplijansa higijene ruku kod studenata na odseku fizioterapije i rehabilitacije nakon kratke edukacije o rukama.

Metod: Pre započinjanja letnje prakse, studenti su bili ukratko edukovani o održavanju higijene ruku. Nakon toga procenjena je njihova komplijansa održavanja higijene ruku. Sociodemografske karakteristike, podaci o kliničkoj letnjoj praksi, kao i komplijansa održavanja higijene ruku zasnovana na preporukama Centra za kontrolu i prevenciju bolesti i njihovim vodi- čima za održavanje higijene ruku, su bili ispitivani sa upitnikom, pripremljenim od strane istraživača.

Rezultati: Od 53 studenta, 52 je ispunilo kriterijume. Prosečna vrednost tačnih odgovora bila je $82,69 \%$. Studenti su imali poteškoća sa izborom adekvatne tehnike za održavanje higijene ruku, kao i u komplijanski sa indikacijama za održavanje higijene ruku u situacijama, koje su u korelaciji sa profesijom. Štaviše, studenti su predložili da je potrebna bolja edukacija $(\mathrm{n}=24,39,34 \%)$ i unapređenje fizičkih uslova $(n=21 ; 34.43 \%)$.

Zaključak: U zaključku se može izneti da su studenti fizioterapije sa rehabilitacijom svesni bitnosti održavanja higijene ruku u cilju prevencije infekcija, 
koje se javljaju na radnom mestu i povezane su sa zdravstvenim sistemom. Kako god, za ovaj odsek, neophodni su programi za higijenu ruku u cilju održavanja optimalne kvalifikacije, kao i da bismo bili u mo-

\section{REFERENCES}

1. Al Kadi A, Salati SA. Hand hygiene practices among medical students. Interdiscip Perspect Infect Dis. 2012; 2012: 679129. doi: 10.1155/2012/679129.

2. Ariyaratne MHJD, Gunasekara TDCP, Weerasekara MM, Kottahachchi J, Kudavidanage BP, Fernando SSN. Knowledge, attitudes and practices of hand hygiene among final year medical and nursing students at the University of Sri Jayewardenepura. Sri Lankan J of Infect Dis. 2013; 3(1): 15-25.

3. Cruz JP, Cruz CP, Al-Otaibi ASD. Gender differences in hand hygiene among Saudi nursing students. Int J Infect Control. 2015; 11(4). doi:10.3396/ijic.v11i4.029.15.

4. Cruz JP, Bashtawi MA. Predictors of hand hygiene practice among Saudi nursing students: a cross-sectional self-reported study. J Infect Public Health. 2016; 9(4): 485-93.

5. Graf K, Chaberny IF, Vonberg RP. Beliefs about hand hygiene: a survey in medical students in their first clinical year. Am J Infect Control. 2011; 39(10): 885-8.

6. Herbert VG, Schlumm P, Kessler HH, Frings A Knowledge of and adherence to hygiene guidelines among medical students in Austria. Interdiscip Perspect Infect Dis. 2013; 2013: 1-6. http://dx.doi.org/10.1155/2013/802930.

7. Ibrahim AA, Elshafie SS. Knowledge, awareness, and attitude regarding infection prevention and control among medical students: a call for educational intervention. Adv Med Educ Pract. 2016; 7: 505-10.

8. Kalata NL, Kamange L, Muula AS. Adherence to hand hygiene protocol by clinicians and medical students at Queen Elizabeth Central Hospital, Blantyre-Malawi. Malawi Med J. 2013; 25(2): 50-2.

9. Mahmood SE, Verma R, Khan MB. Hand hygiene practices among nursing students: importance of improving current training programs. Int J Community Med Public Health. $2015 ; 2: 466-71$

10. Nair SS, Hanumantappa R, Hiremath SG, Siraj MA, Raghunath P. Knowledge, attitude, and practice of hand hygiene among medical and nursing students at a tertiary health care center in Raichur, India. ISRN PrevMed. 2014; 2014: 608927. doi:10.1155/2014/608927.

11. Opara PI, BA Alex-Hart. Hand washing practices amongst medical students in Port Harcourt, Nigeria. The Nigerian Health J. 2009; 9(1-4): 16-20.

12. Shinde MB, Mohite VR. A study to assess knowledge, attitude and practices of five moments of hand hygiene among nursing staff and students at a tertiary care hospital at Karad. IJSR. 2014; 3(2): 311-21.

13. Snow M, White Jr GL, Alder SC, Stanford JB. Mentor's hand hygiene practices influence student's hand hygiene rates. Am J Infect Control. 2006; 34(1): 18-24.

14. Van de Mortel TF, Apostolopoulou E, Petrikkos G. A comparison of the hand hygiene knowledge, beliefs, and practices of Greek nursing and medical students. Am J Infect Control. 2010; 38(1): 75-7. gućnosti da zaštitimo i unapredimo zaštitu zdravstevnih radnika, kao i pacijenata.

Ključne reči: higijena ruku, edukacija fizioterapeuta, studenti.

15. Van de Mortel TF, Kermode S, Progano T, Sansoni J. A comparison of the hand hygiene knowledge, beliefs and practices of Italian nursing and medical students. J Adv Nurs. 2012; 68(3): 569-79.

16. Yaembut N, Ampornaramveth RS, Pisarnturakit PP, Subbalekha K. Dental student hand hygiene decreased with 2ncreased clinical experience. J Surg Educ. 2016; 73(3): 400-8.

17. Bello AI, Asiedu EN, Adegoke BO, Quartey JNA, Appiah-Kubi KO, Owusu-Ansah B. Nosocomial infections: knowledge and source of information among clinical healthcare students in Ghana. Int J Gen Med. 2011; 4: 571-4.

18. Martinez J, Roseira CE, Passos IPBD, Figueiredo RM. Patient'ssafety: knowledge of health students about hand hygiene. Cienc Cuid Saude. 2014; 13(3): 455-63.

19. Tavolacci MP, Ladner J, Bailly L, Merle V, Pitrou I, Czernichow P. Prevention of nosocomial infection and standard precautions: knowledge and source of information among health care students. Infect Control Hosp Epidemiol. 2008; 29(7): 642-7.

20. Centers for Disease Control and Prevention. Guideline for Hand Hygiene in Health-Care Settings: Recommendations of the Healthcare Infection Control Practices Advisory Committee and the HICPAC/SHEA/APIC/IDSA Hand HygieneTask Force. 2002; MMWR 51(RR-16): 1-45. https://www.cdc.gov/ mmwr/PDF/rr/rr5116.pdf (accessed 5 June 2018).

21. Bilici S, Irmak H, Buzgan T. T.C. Sağlık Bakanlığı Temel Sağlık Hizmetleri Genel Müdürlüğü Beslenme ve Fiziksel Aktiviteler Daire Başkanlığı. Sağlık personeline yönelik el yıkama ve el dezenfeksiyonu rehberi. Türkiye: Sağlık Bakanlığı 2008. http://beslenme.gov.tr/content/files/yeterlibeslenme/hijyen/ a18.pdf (accessed 5 June 2018).

22. Smiddy MP, O' Connell R, Creedon SA. Systematic qualitative literature review of health care workers' compliance with HH guidelines. Am J Infect Control. 2015; 43(3): 269-74.

23. Jang JH, Wu S, Kirzner D, Moore C, Youssef G, Tong A et al. Focus group study of hand hygiene practice among healthcare workers in a teaching hospital in Toronto, Canada. Infect Control Hosp Epidemiol. 2010; 31(2): 144-50.

24. Al-Naggar RA, Al-Jashamy K. Perceptions and barriers of hands hygiene practice among medical science students in a medical school in Malaysia. The Int Med J Malaysia. 2013; 12(2): 11-4.

25. Barrett R, Randle J. Hand hygiene practices: nursing students' perceptions. J Clin Nurs. 2008; 17(14): 1851-7.

26. Ward DJ. Infection control in clinical placements: experiences of nursing and midwifery students. J Adv Nurs. 2010; 66(7): 1533-42.

27. Costers M, Viseur N, Catry B, Simon A. Four multifaceted countrywide campaigns to promote hand hygiene in Belgian hospitals between 2005 and 2011: impact on compliance to hand hygiene. Euro Surveill. 2012; 17(18). pii: 20161.

28. McGuckin M, Taylor A, Martin V, Porten L, Salcido R. Evaluation of a patient education model for increasing hand hy- 
giene compliance in an inpatient rehabilitation unit. Am J Infect Control. 2004; 32(4): 235-8.

29. Whitby M, Pessoa-Silva CL, McLaws ML, Alegranzi B, Sax H, Larson E et al. Behavioural considerations for HH practices: the basic building blocks. J Hosp Infect. 2007; 65(1): 1-8.

30. Van de Mortel T, Bourke R, McLoughlin J, Nonu M, Reis M. Gender influences hand washing rates in the critical care unit. Am J Infect Control. 2001; 29(6): 395-9.
31. Ojulong J, Mitonga KH, lipinge SN. Knowledge and attitudes of infection prevention and control among healthsciences students at University of Namibia. Afr Health Sci. 2013; 13(4): 1071-8.

32. O'Brien D, Richards J, Walton KE, Phillips MGA, Humphreys H. Survey of teaching/learning of healthcare-associatedinfections in UK andIrishmedicalschools. J HospInfect. 2009; 73(2): 171-5.

\section{Correspondence to/Autor za korespondenciju}

Ozlem Ozcan

Manisa Celal Bayar University, Faculty of Health Sciences, Department of Physiotherapy and Rehabilitation

(Uncubozkoy Health Campus)

Uncubozkoy M. 5526 Sk. No: 8/4,

45030 Yunusemre/Manisa/Turkey

Mobile phone: +905057063673

e-mail: ozlem.ozcan@cbu.edu.tr 